BORGERHOFF MULDER, M., AND D. SELLEN. 1994. "Pastoral decision-making: A behavioral ecological perspective," in African pastoralist systems: An integrated approach. Edited by E. M. Fratkin, K. A. Galvin, and E. A. Roth, pp. viii, 247. Boulder: Lynne Rienner.

BUKURURA, S. I994. Sungusungu; Vigilantes in West-Central Tanzania. Ph.D. diss., Churchill College, University of Cambridge, Cambridge, U.K.

CAMERER, C., AND E. FEHR, 2002. "Measuring social norms and preferences using experimental games: A guide for social scientists," in Foundations in human sociality: Experiments and ethnography from Is small-scale societies. Edited by J. Henrich, R. Boyd, S. Bowles, C. Camerer, E. Fehr, H. Gin tis, and R. McElreath. Oxford: Oxford University Press.

GALATY, J. G. I988. "Pastoral and agro-pastoral migration in Tanzania: Factors of economy and demography in cultural perspective," in Production and autonomy: Anthropological stud ies and critiques of development. Edited by J. W. Bennett and J. R. Bowen, pp. x, 438. Lanham: University Press of America and Society for Economic Anthropology.

GIL-WHITE, F. 2002. "Ultimatum game with an ethnicity manipulation: Results from the Bulgan Cum, Mongolia," in Foundations in human sociality: Experiments and ethnography from is small-scale societies. Edited by J. Henrich, R. Boyd, S Bowles, C. Camerer, E. Fehr, H. Gintis, and R. McElreath. Oxford: Oxford University Press.

GURVEN, M. 2002. "Does market exposure affect economic game behavior? The ultimatum and public goods game among the Tsimane of Bolivia," in Foundations in human sociality: Experiments and ethnography from is small-scale societies. Edited by J. Henrich, R. Boyd, S. Bowles, C. Camerer, E. Fehr, H. Gintis, and R. McElreath. Oxford: Oxford University Press.

HENRICH, J., R. BOYD, S. BOWLES, C. CAMERER, E. FEHR, H. GINTIS, AND R. MCELREATH, 2OOI. In search of Homo economicus: Behavioral experiments in I5 smallscale societies. American Economic Review 91:73-78.

Editors. 2002. Foundations in human sociality: Experiments and ethnography from is small-scale societies. Oxford: Oxford University Press.

KAGEI, J. H., AND A. E. ROTH. r995. The handbook of experimental economics. Princeton: Princeton University Press.

LANG, G. o. I978. Development in Usukuma, Tanzania. (Studies in Third World Societies 4.) Williamsburg: Department of Anthropology, College of William and Mary.

LITTELL, R. C., R. I. FREUND, ET AL. I99I. SAS System for linear models. Cary, N.C.: SAS Institute.

MARLOWE, F. 2002. "Dictators and ultimatums in an egalitarian society of hunter-gatherers, the Hadza of Tanzania," in Foundations in human sociality: Experiments and ethnography from 15 small-scale societies. Edited by J. Henrich, R. Boyd, S. Bowles, C. Camerer, E. Fehr, H. Gintis, and R. McElreath. Oxford: Oxford University Press.

ORTMANN, A., AND L. TICHY, I999. Gender differences in the laboratory: Evidence from prisoner's dilemma games. Journal of Economic Behavior and Organization 39:327-39.

PACIOTTI, B. 2002. Cultural evolutionary theory and informal social control institutions: The sungusungu of Tanzania and honor in the American South. Ph.D. diss., Graduate Group in Ecology, University of California, Davis, Calif.

RICHERSON, P. J., AND R. BOYD. I999. Complex societies: The evolutionary origins of a crude superorganism. Human Nature: An Interdisciplinary Biosocial Perspective ro:253-89.

SMITH, E. A., M. BORGERHOFF MULDER, AND K. HILL. 2OOI. Controversies in the evolutionary social sciences: A guide for the perplexed. Trends in Ecology and Evolution 16 : I28-35.

VARKEVISSER, C. M. I973. Socialization in a changing society: Sukuma childhood in rural and urban Mwanza, Tanzania. The Hague: Centre for the Study of Education in Changing Societies.

WILLIS, R. G., AND INTERNATIONAL AFRICAN INSTITUTE. I996. The Fipa and related peoples of south-west Tanzania and north-east Zambia. (Ethnographic Survey of Africa:
East Central Africa, pt. 15.) London: International African Institute.

\section{Selfishness and Fairness in Economic and Evolutionary Perspective: An Experimental Economic Study in Papua New Guinea $^{1}$}

\author{
DAVID P. TRACER \\ Department of Anthropology and Program in Health \\ and Behavioral Sciences, University of Colorado at \\ Denver, P.O. Box 173364, Campus Box I88, Denver, \\ Colo. 80217 , U.S.A. (dtracer@carbon.cudenver.edu). \\ $22 \times 02$
}

Although often seen as among the most idealistic and the most dismal of sciences respectively, the disciplines of anthropology and economics in fact have much in common. Both are concerned with understanding and predicting regularities and variability in human behavior, and both have historically studied human behavior in more or less "natural" environments (cultures, societies, populations, and markets). Moreover, unlike some social and natural sciences, they have historically shunned experimental manipulation of subjects. The similarities between evolutionary anthropology and economics are even more apparent, with both postulating that human behaviors (and, for the former discipline, aspects of morphology as well) are designed to maximize some outcome. According to most economists, humans behave in the service of maximizing utility, the usefulness or satisfaction provided by some preferred good, activity, or balance thereof. In industrialized societies, where access to individuals' preferred goods and activities is facilitated largely through monetary transactions, most economists expect them to behave as maximizers of material payoffs. For scientists guided by the logic of evolutionary theory, behavior is designed to maximize fitness, the proportional representation of an individual's genes in succeeding generations. Fitness maximization,

(C) 2003 by The Wenner-Gren Foundation for Anthropological Research. All rights reserved oOII-3204/2003/4403-0009\$1.00

I. This study was carried out with funding from the John D. and Catherine T. MacArthur Foundation "Preferences Network" headed by Herbert Gintis and Robert Boyd. I thank Susan Blum, John Brett, Peter Dwyer, Ernst Fehr, Ben Orlove, Duane Quiatt, Tammy Stone, and three anonymous reviewers for their helpful comments on the manuscript and Sara Wyckoff and Matthew Wimmer for their assistance in the field. [Supplementary material appears in the electronic edition of this issue on the journal's web page (http://www.journals.uchicago/edu/CA/home.html).] 
a function of reproductive success, is achieved by females by maximizing access to and consumption of resources necessary to sustain the energetically costly physiological states of pregnancy and lactation. For males, fitness maximization is achieved by maximizing mating opportunities, but in higher primate species such as chimpanzees and humans access to females has itself been demonstrated to be a function of male resource holdings (Kaplan and Hill r985, Perusse 1993, Stanford I996). For many economists and evolutionarily oriented behavioral scientists, then, humans are expected to act as rational resource maximizers in the service of utility and fitness respectively.

There is, however, at least one critical distinction between an evolutionary and an economic view of human behavior that is often overlooked. The normative economic view of humans as utility maximizers posits that individuals are completely self-regarding; they try to maximize their own individual utility quite independently of others. For this reason, individuals are expected to be maximizers of absolute material payoffs and to attempt to increase their own stores of capital, regardless of effects on others in the population. By contrast, evolutionary anthropologists view humans as fitness maximers who amass capital, utility, and the like not as an end in itself but specifically in the service of fitness maximization. This requires that, when competing with individuals in dyadic interactions, individuals behave as maximizers of relative material payoffs and be otherregarding. For example, if an individual $\mathrm{X}$ is faced with making a decision that will yield higher utility benefits to $\mathrm{Y}^{2}$ compared with his or her own payoff, $\mathrm{X}$ should only make that decision if his or her ability to translate each unit of material payoff into fitness is proportionately higher than Y's such that the decision yields a net fitness gain for X. This conditional decision making is simply a form of Hamilton's (1964) fundamental equation for the evolution of social behavior.

Recently, economists have with increasing frequency employed experimental tools, also referred to as "games," that aim to measure certain human behavioral propensities such as risk aversion, altruism, selfishness, and reciprocity in ways that are minimally invasive (Gintis 2000). These methods can also be used to gauge whether individuals seem to be self-regarding and try to maximize absolute payoffs as predicted by the normative economic model or whether they care about the behavior of others and try to maximize their payoffs relative to them as predicted by the evolutionary model. One of the simplest games commonly performed by experimental economists is the "ultimatum game." In this game, two individuals, a "proposer" and "responder," play anonymously with one another. The proposer specifies how a given sum of money will be divided between them, and the responder then has the opportunity to accept or reject

2. The assumption here is that individuals $\mathrm{X}$ and $\mathrm{Y}$ are unrelated. Where this assumption is violated, in addition to each individual's ability to convert utility into fitness, the coefficient of relatedness, $\mathbf{r}$, between the individuals must also be taken into account. the offer. If the offer is accepted, then the sum of money is divided as specified; if it is rejected, then both individuals receive nothing. According to classic economic expectations-that humans behave as self-regarding maximizers of absolute payoffs-it is relatively easy to predict how individuals should behave in the ultimatum game: responders should accept any nonzero offer proposed to them, since rejection means that they earn zero. Moreover, knowing that responders should be willing to accept any nonzero offer, proposers are expected to offer them the smallest nonzero sum possible in the game. The expectations under the logic of evolutionary theory differ, however. Under the condition that each unit of payoff is equally valuable to proposers and responders, offers that, if accepted, yield less for responders than for proposers should be rejected, while offers that yield an even take or better for responders should be accepted. Knowing that responders tend to reject offers that are less than $50 \%$ of the stakes, proposers are expected to have a propensity to offer them $50 \%$.

The results of an ultimatum game conducted crossculturally in the industrialized cities of Pittsburgh (U.S.A.), Tokyo (Japan), Ljubljana (Slovenia), and Jerusalem (Israel) deviated significantly from classic economic predictions (Roth et al. I99I). The lowest possible nonzero proposals made up fewer than I\% of all proposals, modal offers by proposers generally approached $50 \%$ of the total stakes, with the mean offer ranging from a low of $37 \%$ (Israel) to a high of $47 \%$ (U.S.A.), and rejection rates by responders varied between $19 \%$ and $27 \%$, with offers below $20 \%$ commonly being rejected (Camerer n.d., Roth et al. I991). The deviations from economic predictions, in particular the higher than expected offers and rejection of relatively low offers, have been seen by economists (Roth I995) as indicating a taste for fairness as well as a tendency to punish those not showing similar tastes. However, behavior in these games and the "taste for fairness" itself are consistent with an evolutionary paradigm that sees individuals as other-regarding and concerned about maximizing payoffs relative to others. Interestingly, the idea that "fairness" and the performance of others matter to responders is lent credence by the fact that low offers are rejected significantly less often when responders either do not know the size of the total stakes and are therefore unable to judge the fairness of the offer or are informed that the offer was computer-generated (Fehr and Gächter I998).

In contrast to the results obtained from ultimatum experiments in relatively industrialized settings, those of Henrich's (2000) experiment with 32 pairs of Machiguenga swidden horticulturalists in the Peruvian Amazon more nearly approached classic economic predictions. Among the Machiguenga, the modal offer was I $5 \%$, and except for one case all offers were accepted. Henrich has argued that the contrast between his results and those of Roth et al. (I99I) (table I) indicates the possibility that culture may play a profound role in determining "what is perceived as 'fair.' " An interesting complementary explanation can be derived from Telser's (r995) supply-and-demand theory of fairness. Telser ar- 
TABLE I

Mean and Modal Offers (Percentage) and Rejection Rates in One-Shot Ultimatum Bargaining Games Conducted in Four Urban Areas (Roth et al. 1991) and among the Machiguenga of Peru (Henrich 2000)

Location $n$ Modal Offer Mean Offer Rejection Rate

\begin{tabular}{lllll} 
Pittsburgh & 27 & 50 & 47 & .22 \\
Tokyo & 29 & 50 & 42 & .24 \\
Ljubljana & 30 & 50 & 46 & .27 \\
Jerusalem & 30 & 50 & 37 & .27 \\
Machiguenga & 21 & 15 & 26 & .04 \\
\hline
\end{tabular}

gues that where wealth is low and even a small percentage of the total stakes offers a relatively high marginal increase in wealth, the cost of demanding fairness and inflicting punishment is high and therefore the demand for fairness will decline. In the case of the $\mathrm{Ma}$ chiguenga, the propensity of responders never to reject offers may indicate the relatively high value of the stakes to the players. Of course, this does not negate the explanation offered by Henrich, that the Machiguenga also have culturally specific norms of "fairness" that differ from those in the more Westernized societies studied by Roth et al.

In order to test predictions derived from evolutionary versus economic theory and to examine the role of the cultural milieu in shaping the outcome of economic experiments, results are presented of an ultimatum-game experiment conducted in June and July 1998 among the $\mathrm{Au}$ and the Gnau of Sandaun Province, Papua New Guinea.

\section{THE STUDY POPULATIONS}

The two villages in this study, Anguganak and Bogasip, occupy the southern foothills of the Torricelli Mountains roughly $50 \mathrm{~km}$ inland from the north coast of Papua New Guinea. They are located only $1.5 \mathrm{~km}$ from one another but speak different languages, $\mathrm{Au}$ and Gnau. Villagers are also conversant in Neo-Melanesian (Tok Pisin), the lingua franca of Papua New Guinea, and because I am proficient in Au but not in Gnau this study was conducted predominantly in Neo-Melanesian.

The villagers of Anguganak and Bogasip practice a mix of foraging and swidden horticulture. Their principal dietary staple is starch extracted from sago palms, which is generally consumed with a stew of leaves and meat or insect larva, if available, boiled in coconut cream. Organized daytime hunts for large game (pigs and cassowaries) and night hunts for nocturnal mammalian prey (bandicoot, cuscus) are conducted by men, while women hunt opportunistically, procuring protein from animals encountered by chance during their daily foraging rounds. Pig husbandry is also practiced, though in contrast to the situation in the highlands it is uncommon for $\mathrm{Au}$ or Gnau families to own more than one or two pigs. As in the highlands, however, pigs are a source of wealth and prestige and are killed only infrequently, for ceremonial occasions.

One element common to Au and Gnau societies that is relevant to the current study is an elaborate system of exchange relationships. Some of these relationships are obligatory and quite standardized, while others are to some degree optional and certainly less standardized. Many of these exchange relationships are described by Lewis (1975) in his ethnography of the Gnau. Although no ethnography of the Au has been published, my fieldwork among them over the past $\mathrm{I}_{3}$ years has revealed patterns of exchange, obligation, and indebtedness that are nearly identical to those of the Gnau. Just a few of these exchange relationships are described below.

Animal protein procured by men is distributed among the hunter's family and his extended kin, but both the $\mathrm{Au}$ and the Gnau have a strict taboo against hunters' consuming their own kills. This taboo is part of a larger prohibition against "consuming one's own body" that extends into many areas of everyday life. In the domain of hunting, because animals are shot with arrows that have been carried by the hunter next to his body, it is believed that the hunter's sweat and "body dirt" adhere to the arrows and enter the animal when it is shot. The hunter is thus prohibited from consuming the animal because it contains "his own body" and is required to distribute it to others. Although I had been told that hunters who deviated from distributing shares of meat according to prescribed practices might be shunned, a violation of the prescribed sharing norms observed during the 1998 field season actually led to more severe punishment. The wife of the offending party was repeatedly verbally assaulted by villagers and was finally struck on the head with a large tree branch. The punishment was viewed by others in the village as severe but justified. By the I999 field season this family had actually fled the village and taken up residence in the wife's natal village.

In addition to sharing of meat, some of the most welldefined exchanges are centered around marriage. Although it is preferred that a man marry his father's father's mother's brother's son's son's daughter, in fact many marriages do not follow this pattern but are decided by the prospective groom in concert with the prospective bride's father and brothers. Once a marriage is agreed upon, a bride price is set and paid in installments by the groom with help primarily from his agnates and to a lesser extent from his matrilateral relatives and unrelated hamlet coresidents (Lewis I975). Before the bride price is fully paid, the bride periodically visits the groom's hamlet and works in food production with his mother for short (one- or two-week) spans of time. When it is fully paid, there is a "sending ceremony" in which the bride's hamlet formally sends her with gifts of food and betel nut to her husband's hamlet. With this ceremony full rights over the woman are transferred to her husband, and members of her natal hamlet smear their faces with mud and observe a brief mourning period. Once a child is produced, the bride price is then distributed among the woman's male relatives (i.e., her father, 
father's brothers, and brothers). Subsequent events that occasion additional payments by a husband to his wife's male kin (especially her eldest brother or, in some cases, the brother who precedes her in birth order) include the birth of his first child, the child's first consumption of meat, the child's reaching puberty and undergoing initiation, the death of his wife, and the death of his first son. In exchange for these payments, it is the duty of the maternal uncle to see to it that his sister's sons and daughters grow properly by hunting and providing them with meat and by performing their initiation rites at puberty (Lewis I980). Violations of any of these prescribed exchange norms may result in violence among the involved parties.

Apart from formal exchange obligations between individuals and relatives, the $\mathrm{Au}$ and the Gnau place a high premium on generosity. If a coresident of one's hamlet (and sometimes even a noncoresident) asks for something, one is expected to give the item requested. Items requested may include food, clothing, household goods, string bags, tools, or money. In Anguganak, for example, the Au request aoto mas (Give me betel nut) is one of the most frequently heard utterances, and if the individual indeed has betel nut the request must honored. Similarly, aoto taanik (Give me [your] string bag), aoto hrina (Give me [your] knife), aoto sak nan (Give me pig meat), while less commonly heard, must also be honored. People who are known to possess the items requested but refuse to honor requests are shunned and may not have their own requests honored, especially if they are repeat offenders. Stinginess may also on occasion be punished by violence. For this reason, many $\mathrm{Au}$ and Gnau prefer to be discreet about what they do or do not possess. Nocturnal hunters, for example, who commonly hunt alone, will often sneak into the hamlet before sunrise and hide whatever quarry they have obtained. In addition to those who do not honor requests, people who make too many requests may also be shunned, talked about scathingly, and retaliated against by making many requests of them. Making requests and having them honored is thus considered a right but one that must not be abused.

Individuals may also at times display generosity by giving unsolicited items, such as meat, to others. Acceptance of these items binds the individuals in a reciprocal relationship with one another. It is understood by both that a debt has been incurred and that at some future time it will be repaid either with or without a specific request to do so. As has been noted for a number of societies, the creation of obligations through gift giving presumably acts both as an insurance policy and as a generator of prestige for the giver (Mauss I967, Sahlins I972). It is thus a form of "social capital" and can create conflict between the parties involved: "In principle there can be a struggle between a person wanting to do a favor for another and the other not wanting to have the favor done for him" (Coleman I990:3 Io). Indeed, among both $\mathrm{Au}$ and Gnau unsolicited offers are sometimes refused.

\section{EXPERIMENTAL METHODS}

The stakes of the experiment were set at ro kina (Kro), which is equivalent to an upper-end day's wage for an unskilled laborer. However, as most people in the area do not have a source of wage income, this was considered by most of the participants to be a large sum. In order to recruit volunteers, a meeting was set up in a central location in each of the villages. At the meeting, it was explained that participation was completely voluntary, all participants would be compensated with the sum of $\mathrm{K}_{3}$, and only married adult individuals could participate. To prevent the possibility of collusion, the details of the experiment were not explained at the meeting, but participants were told that in contrast to some research in the past (Tracer 1996, 1997) the current project did not involve any invasive procedures, participants would be assured of anonymity, and the work entailed the possibility that participants could garner between Ko and Kro in addition to the $\mathrm{K}_{3}$ compensation fee.

At Anguganak, the experiment was performed over the course of one week in a variety of locations as individuals willing to participate were encountered throughout three village hamlets. In Bogasip, the experiment was performed over the course of two days in a small covered meeting area in the village to which individuals came one at a time to participate. In both villages, a standard Neo-Melanesian script was used to explain the rules of the game.

Individuals participating in the experiment were initially given their $\mathrm{K}_{3}$ participation fee. Their attention was then focused on a cloth upon which ten KI coins were laid out in a row, and a standard script was recited that explained the rules of the game (see Tracer 2002). Following the script reading, individuals were asked if they had any questions. Many individuals had no questions, though the most common question posed by both proposers and responders was whether the money was really theirs to keep.

After the reading of the script, a period of testing followed in which proposers were presented with a standardized roster of offer amounts and asked how much they and the responders would receive if the responders accepted or refused the offer. Responders were also tested by presenting them with the same roster of offer amounts and asking them how much they and the offerers would receive if they accepted or refused each offer. The testing revealed lapses in participants' understanding of the experiment's rules. Indeed, on many occasions the script supplemented by additional explanation was presented twice and in several instances three times. In six cases, repeated testing revealed that even after repeated explanation the individuals did not understand the rules of the game, and they were excluded from participating though still paid $\mathrm{K}_{3}$. In general, the greatest amount of confusion about and (re)explanation of the experiment's rules occurred among the most elderly participants.

The final sample consisted of I Io individuals: 30 pairs of participants at Anguganak and 25 pairs of participants at Bogasip. The first 30 individuals at Anguganak and 25 
at Bogasip were assigned the role of "proposer," and the next 30 and 25 at the two villages respectively were assigned the role of "responder." Proposers and responders were always paired within the same village but randomly with respect to age and gender. After proposers and responders had participated, they were told that their decisions would never be divulged to others even after the experiment was over and were asked not to discuss the experiment with other villagers. A lack of distinct temporal trends in offer amounts, acceptance or rejection of offers, and the fact that understanding of the experiment did not appear to increase with time strongly suggest that participants heeded this request and certainly that there was no collusion among them. Payouts were made after all proposers and responders at each village had participated (i.e., at the end of one week at Anguganak and at the end of two days at Bogasip).

The final sample of $\mathrm{I}$ Io individuals was $53 \%$ male and $47 \%$ female. Of those, $50 \%$ of males were assigned the role of proposers and $50 \%$ the role of responders. Of the females in the sample, $48 \%$ were proposers and $52 \%$ were responders. Age ranged from 17 to 72 years with a mean of 37.5 (s.d. $=$ r 4.7 ).

\section{RESULTS}

Table 2 shows the distribution of amounts offered by proposers in the one-shot ultimatum experiment $(n=$ 55). There were no offers of $\mathrm{Ko}, \mathrm{K} 8$, or Kio, and the modal offer, totaling $27.3 \%$ of all offers, was $\mathrm{K}_{3}$ or $30 \%$ of the stakes. There were strong secondary and tertiary modes at $\mathrm{K}_{4}$ and $\mathrm{K}_{5}$ (totaling $25.5 \%$ and $20.0 \%$ of all offers, respectively). The mean offer was $40.7 \%$ (s.d. $=$ r.6).

Figure I shows the distribution of offers accepted and rejected by responders $(n=55)$. By far the most striking element of this figure is the very high rejection rate. The overall rejection rate for all offers was an astonishingly high $32.8 \%$. This included rejection of $80 \%$ of offers of $\mathrm{K}_{2}(4$ of 5$), 20 \%$ of offers of $\mathrm{K}_{3}\left(3\right.$ of $\left.\mathrm{I}_{5}\right), 42.9 \%$ of offers of $\mathrm{K}_{4}$ ( 6 of I4), $\mathrm{I} 8.2 \%$ of offers of $\mathrm{K}_{5}$ ( 2 of $\mathrm{II}$ ), and, most

TABLE 2

Frequency of Offers (in Kina) Made by Proposers in the Ultimatum Game at Anguganak and Bogasip

\begin{tabular}{lrr} 
Offer Amount & $n$ & Percentage \\
\hline & & \\
0 & 0 & 0.0 \\
I & 2 & 3.6 \\
2 & 5 & 9.1 \\
3 & I 5 & 27.3 \\
4 & I4 & 25.5 \\
5 & II & 20.0 \\
6 & 2 & 3.6 \\
7 & 5 & 9.1 \\
8 & 0 & 0.0 \\
9 & I & 1.8 \\
IO & 0 & 0.0 \\
Total & 55 & I00.0 \\
\hline
\end{tabular}

NOTE: Mean offer $=4.07$, s.d. $=1.6$.

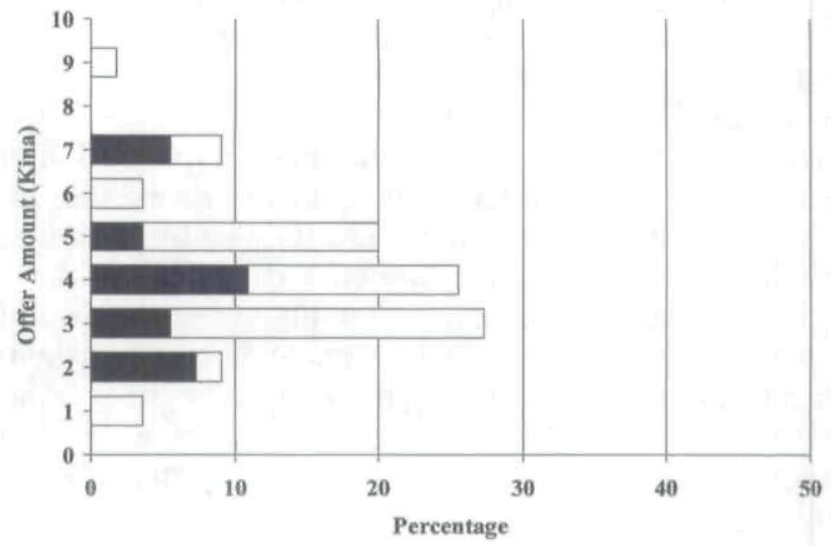

FIG. I. Distribution of accepted and rejected offers ( $\mathrm{n}=$ $55)$ in an ultimatum game in Papua New Guinea. Black bars, rejected; white bars, accepted. Modal offer = $30.0 \%$; mean offer $=40.7 \%$.

intriguing, $60 \%$ of offers of $\mathrm{K}_{7}(3$ of 5$)$. These high rejection rates certainly run counter to the economic expectation that individuals behave as self-regarding utility maximizers. Moreover, while the high rejection rate of offers below the mode may indeed show a reasonably widespread disdain among responders for unfair offers, the very high rejection rate of both fair $(50 \%)$ and "hyperfair" $(>50 \%$ ) offers (totaling just over $26 \%$ of all such offers) is seemingly difficult to explain using solely economic or evolutionary premises. As noted below, however, the rejection of hyperfair offers does make sense within the broader cultural milieu of the $\mathrm{Au}$ and the Gnau and in this regard may corroborate Henrich's (2000) notion that broader cultural norms play a profound role in influencing the outcome of economic experiments.

The relationship of offer amounts and acceptance and rejection rates with gender was also explored. As illustrated in figure 2, among both males and females there were two equally common offers. The modes for males were $\mathrm{K}_{4}$ and $\mathrm{K}_{5}$, while those for females were slightly lower at $\mathrm{K}_{3}$ and $\mathrm{K}_{4}$. Despite the higher male modes, however, the distribution of male offers was slightly skewed toward lower offers while that of females tended to be slightly skewed toward higher offers. As a result, the mean offer among female proposers was $\mathrm{K}_{4} .4$, while among male proposers it was $\mathrm{K}_{3} .8$. The difference in offer distributions by gender did not, however, reach the level of statistical significance (Kolmogorov-Smirnov test, $p=$ $.50)$.

\section{DISCUSSION}

The level of offers seen in this ultimatum experiment falls between those obtained among industrialized populations and among Machiguenga horticulturalists of Peru. Roth et al. (I99I) reported that in Pittsburgh, Tokyo, Ljubljana, and Jerusalem modal offers were $50 \%$ of the stakes. Mean offers in these countries ranged from 


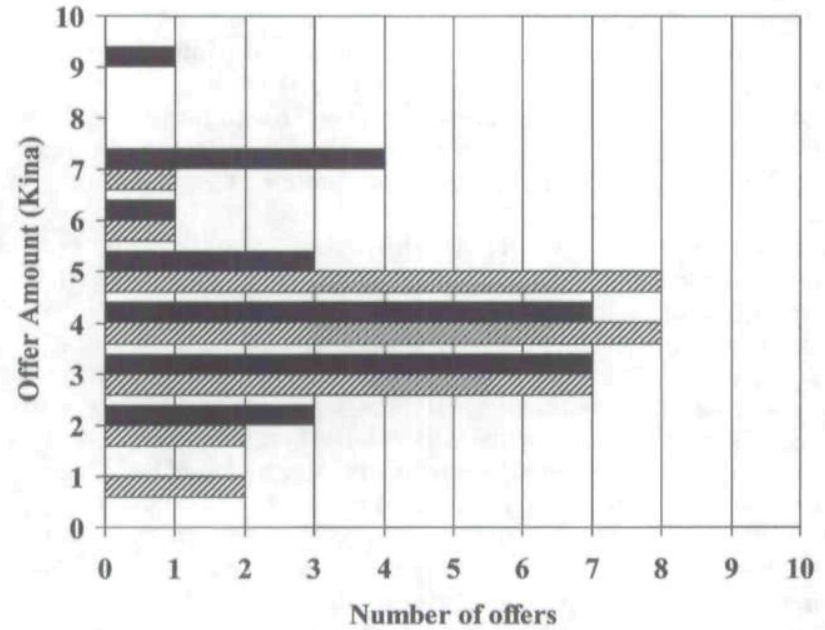

FIG. 2. Distribution of offers $(\mathrm{n}=55)$ by gender in an ultimatum game in Papua New Guinea. Black bars, females; shaded bars, males.

$37 \%$ of the stakes in Jerusalem to $47 \%$ of the stakes in Pittsburgh. By contrast, Henrich (2000) found a modal offer of $15 \%$ and a mean offer of $26 \%$ among the Machiguenga. Anguganak and Bogasip showed a modal offer, $30 \%$, between that of the Machiguenga and the industrialized countries, but the distribution of offers was such that the mean offer, almost $4 \mathrm{r} \%$, was closer to that of the industrialized countries than to the Machiguenga. As discussed earlier, the $\mathrm{Au}$ and the Gnau have an elaborate system of formal exchange obligations and place a very high premium on generosity and fulfilling requests. In fact, the obligation to fulfill requests often results in individuals' being quite secretive about what they possess. It is likely that the value placed upon generosity in these villages played some role in generating the relatively high mean offer seen in this experiment. This supports Henrich's (2000) contention that "culture matters" in economic behavior. It does not support the economic expectation that individuals act as purely self-regarding utility maximizers or the proposition advanced by some that these self-regarding tendencies should be exhibited more among less Westernized populations than among those living in the industrialized world.

In I998, Eckel and Grossman reported the results of a double-anonymous "dictator" experiment indicating that women had a tendency to be more generous and less "individually oriented" than men. Gender-specific results of the ultimatum game at Anguganak and Bogasip show that the distribution of offers by women was skewed toward higher offers while that of men was skewed toward lower offers. Although the difference in the distributions by gender did not reach the level of statistical significance, the gender-specific trends may offer some provisional corroboration of Eckel and Grossman's findings.

By far the most interesting finding of this study was the very high rate of rejection of offers by responders. The overall rejection rate was almost $33 \%$, the highest seen anywhere in the world. For comparison, rejection rates varied between $22 \%$ and $27 \%$ in the four developed nations studied by Roth et al. (I99I), and most rejections occurred in instances where very low offers were proposed. Among Au and Gnau, however, the highest rates of rejection were seen in response to both the lowest and the highest offers ( $80 \%$ and $60 \%$ respectively).

The rejection of low offers seen here is inconsistent with the economic view of humans as purely self-interested absolute payoff maximizers. Instead, it is more consistent with the evolutionary view that, assuming a constant ability among individuals to translate material payoffs into fitness, individuals should be expected to reject grossly unbalanced offers.

Clearly, whether humans are seen as absolute or relative payoff maximizers, the remarkably high rejection rate of "hyperfair" offers seen here but nowhere else in the world is, at face value at least, inexplicable in terms of either model. Instead, it is certain that these high rejection rates result from cultural beliefs about generosity and the necessity of repaying debts coupled with a lack of previous exposure to "impersonal transactions." As noted earlier, Au and Gnau at times display generosity by giving unsolicited gifts, and their acceptance binds the two individuals in a reciprocal relationship. It is understood by both the gift giver and its receiver that a debt has been incurred and that at some future time it must be repaid. Unsolicited offers are therefore sometimes refused, especially if the potential receiver does not wish to become indebted to the giver. This rejection of unsolicited offers is unlikely to occur with low-value items that are easy to repay (such as betel nut) but more likely to occur with higher-valued items (such as pig meat).

It is also worth noting that all transactions among $\mathrm{Au}$ and Gnau are "personal" and conducted in a face-to-face fashion. Anonymity and impersonal transactions are completely unknown. Thus even though both proposers and responders were assured that their identities would be safeguarded, the idea that anyone would give money to an anonymous second party was foreign to them, and thus it was equally unbelievable that they would not at some point in the future be responsible for compensating the proposer for the generosity. When individuals rejected offers, they commonly made remarks such as "I can take the $\mathrm{K}_{3}$ I received from you, I can't take money from someone in the village." When offered sums above $\mathrm{K}_{5}$, they often seemed genuinely afraid, and on several occasions responders said, "No, that's too much." Thus, individuals in all likelihood believed that they would be held accountable in some way for the money they might receive and feared having to pay back such relatively high sums. The cognitive mapping of unfamiliar economic games on established cultural norms and familiar local institutions has also recently been reported by Ensminger (2000) among the Orma of Kenya.

Overall, the propensity of responders in both this and other ultimatum-game studies to reject low offers sug- 
gests that humans behave as relative rather than absolute maximizers of material payoffs. While this behavior is inconsistent with the prevailing assumption in economics, contra some recent contentions (Sigmund, Fehr, and Nowak 2002), it is entirely consistent with the evolutionary expectation that humans will be motivated to maximize material gain only insofar as it affects relative fitness. But the data presented here, particularly on offer rejections, also seem to suggest that the cultural milieu plays a profound role in affecting experimental game play. Rejection of low or "unfair" offers, while consistent with evolutionary expectations, is also consistent with the strong $\mathrm{Au}$ and Gnau valuation of generosity. The rejection of "hyperfair" offers in the anonymous game environment is likely due to the unfamiliarity of the participants with impersonal transactions and their propensity in the game as in real life to guard against incurring high-cost reciprocal obligations. Overall, these results suggest that, when used in concert with ethnography, experimental economic methods may provide useful new tools to anthropologists interested in studying behaviors such as reciprocity, fairness, risk aversion, cheating, and punishment in human societies.

\section{References Cited}

CAMERER, C. n.d. Simple bargaining and social utility: Dictator, ultimatum, and trust games. MS.

COLEMAN, J. S. I990. The foundations of social theory. Cambridge: Harvard University Press.

ECKEL, C. C., AND P. J. GROSSMAN. 1998. Are women less selfish than men? Evidence from dictator experiments. Economic Journal ro8:726-36.

ENSMINGER, I. E. 2000. "Experimental economics in the bush: How institutions matter," in Institutions and organizations. Edited by Claude Menard. London: Edward Elgar.

FEHR, E., AND S. GÄCHTER. I998. Reciprocity and economics: The economic implications of Homo reciprocans. European Economic Review 42:845-59.

GINTIS, H. 2000. Game theory evolving: A problem-centered introduction to modeling strategic interaction. Princeton: Princeton University Press.

HAMILTON, W. D. 1964. The genetical evolution of social behavior. Journal of Theoretical Biology 7:1-52.

HENRICH, I. 2000. Does culture matter in economic behavior? Ultimatum game bargaining among the Machiguenga Indians of the Peruvian Amazon. American Economic Review 90: 973-80.

K APLAN, H., AND K. HILL. 1985. Hunting ability and reproductive success among male Ache foragers. CURRENT ANTHROPOLOGY 26:223-45.

LEWIS, G. I975. Knowledge of illness in a Sepik society: A study of the Gnau, New Guinea. London: Athlone Press.

1980. Day of shining red: An essay of understanding ritual. Cambridge: Cambridge University Press.

MAUSs, M. 1967. The gift: Forms and functions of exchange in archaic societies. New York: W. W. Norton.

PERUSSE, D. I993. Cultural and reproductive success in industrial societies: Testing relationship at the proximate and ultimate levels. Behavioral and Brain Sciences r6:267-322.

ROTH, A. E. I995. "Bargaining experiments," in The handbook of experimental economics. Edited by J. H. Kagel and A. E. Roth, pp. 253-348. Princeton: Princeton University Press.

ROTH, A. E., V. PRASNIKAR, M. OKUNO-FUIIWARA, AND S. ZAMIR. I99I. Bargaining and market behavior in Jerusalem, Ljubljana, Pittsburgh, and Tokyo: An experimental study. American Economic Review 8r:1068-95.

SAHLins, M. 1972. Stone Age economics. New York: Aldine.

SIGMUND, K., E. FEHR, AND M. A. NOWAK. 2002. The economics of fair play. Scientific American 286:83-87.

STANFORD, C. B. 1996. The hunting ecology of wild chimpanzees: Implications for the evolutionary ecology of Pliocene hominids. American Anthropologist 98:96-113.

TELSER, L. G. I995. The ultimatum game and the low of demand. Economic Journal 105:1519-23.

TRACER, D. P. I996. Lactation, nutrition, and postpartum amenorrhea in lowland Papua New Guinea. Human Biology 68:277-92.

r997. Reproductive and socio-economic correlates of maternal haemoglobin levels in a rural area of Papua New Guinea. Tropical Medicine and International Health 2:5 $13-18$. . 2002. "Market integration, reciprocity, and fairness in rural Papua New Guinea: Results from a two-village ultimatum game experiment," in Cooperation, reciprocity, and punishment: Experiments from I5 small-scale societies. Edited by I. Henrich, R. Boyd, S. Bowles, C. Camerer, E. Fehr, H. Gintis, and R. McElreath. Oxford: Oxford University Press. 
Copyright of Current Anthropology is the property of Wenner-Gren Foundation and its content may not be copied or emailed to multiple sites or posted to a listserv without the copyright holder's express written permission. However, users may print, download, or email articles for individual use. 
Copyright of Current Anthropology is the property of Wenner-Gren Foundation and its content may not be copied or emailed to multiple sites or posted to a listserv without the copyright holder's express written permission. However, users may print, download, or email articles for individual use. 